\title{
Is Albanian Stock Market Functioning as its European Counterparts?
}

\author{
Phd.c. Evarist Beqiri \\ Phd Candidate, Faculty of Law, Univerisity of Tirana, Albania \\ evaristbeqiri@yahoo.com \\ Phd.c. Saimir Shatku \\ Tirana University, Faculty of Law, Albania \\ Department of Organization and Management, Sports University of Tirana, Albania \\ Email: s_shatku@yahoo.com
}

Phd.c. Mimoza Sadushaj

Departament of Civil Law, Faculty of Law, Tirana Univrersity President of the Notary Chamber of the Republic of Albania mozasadushaj@gmail.com

Doi:10.5901/ajis.2015.v4n1p185

\section{Abstract}

This study aims to analyze the causes and the factors behind the dysfunctionality of the Albanian Stock Market. Even though that the stock market and securities one is provided and regulated by the Albanian legislation, practice has not seen too much development. This paper will be seen from a historical perspective having in focus the democratic transition years of Albania, since the fall of the communist regime, which is also the period when the capitalist and democratic ways were reapplied in Albanian society.

Keywords: Stock Market, Albania, dysfunctionality, causes, European markets.

\section{Introduction}

It is difficult to localize where and when stock markets begin to exist for the first time. However, it is thought that the strands have been in Mesopotamia, the disclosure of debts to different traders. This practice continued with Roman civilization and was also attended by famous Venetian merchants public debts began to write on pieces of paper and to keep the public (IH Instituti i Historise , 2002), exposed around the city, so that each individual could know who owed debt to whom. This tradition started in Venice was followed and it took a relatively long time the stock market to take the form it has today.

The main practice, upon which it relied in time we are talking about, has been publishing large debts that the merchants had to each other. The failure to pay on time brought the necessity of the disclosure of debts. As a result of the growth of monetary circulation, increased diversity of goods and the emerging of new forms of currency initially bore the concept of trader and later, banks were created. Historically, all stock markets in the beginning were an integral part of the banks. But as it began to receive some features, different, which the banks had not seen until then, stock markets won a personality of their own independent of the banks. In the period under discussion and for the reasons mentioned above, banks focused more on the provision of loans (IH Instituti i Historise, 2002). This was one of the factors behind the difference between the two and the banks began to see the Stock Exchange as the market in which they could participate.

A stock market is legally organized as a joint stock company with two levels, referred to Albanian law for Entrepreneurs and Companies (Law No. 9901, dated 14.4.2008 "For traders and companies." (Amended), Articles 105 and following. www.qpz.gov.al). In its bodies, the stock market should have necessarily a Management Board and a Supervisory Board, who have the competencies set out in the Statute of the stock. From the functional point of view, the stock exchange is a market which is governed by simple laws of demand and supply. In this market the sellers try to sell expensively, while those who buy want to buy the cheapest. Participants most recognized of the stock market, but not 
only, are the Brokers and Dealers. A broker sells and buys the stock exchange in the name and for its own account, while a Dealer acting in the name and for the account of others.

Stock market of Securities is a market specifically established and organized to face the flow of demands and supplies of securities of movable property, issued by joint ventures, from the state and other public entities (AMF, 2009). Thus, the special element we see in this market is the existence of entities with public power, participating in completely equal conditions and even subjects from around the world. Advantages of the stock today are visible, we can mention here: the diversity of titles offered, price transparency, real-time recognition of trends in purchases and sales continuing with minimum costs of conducting transactions desired (LSE, September, 2012). Today more than ever stock market role in the world's economy is strongly felt and they appear as the first alarm signals, which are lit in case of a crisis. In the same way it appears the stability of financial markets in the stock market is affecting the stability of macro and micro economic terms in general.

\section{The Causes Behind the Dysfunctionality of the Albanian Stock Market}

Albanian Stock Market is regulated by the law "On Entrepreneurs and Companies" and the law "On Securities" (Law No. 9879, date 21.02.2008 "On Securities" www.qpz.gov.al access date 18/01/2015). Originally ASM (Albanian Stock Market) was established as an integral part of the Central Bank of the Republic of Albania, taking the example of its counterparts in the region. The scope of the ASM is to create a capital market or securities by establishing a market system through which "offers for sale, purchase or exchange are regularly performed or accepted; supplies or demands are regularly performed when being predefined or are expected, which result directly or indirectly in making or acceptance of offers for sale, purchase, or exchange of securities or in giving regular information on prices and rewards to individuals or specific groups proposing or expect to sell, buy or exchange securities" (com, 2010).

Today securities in Albania have little liquidity especially compared to the rest of the goods, products or money itself. Till now, there are not statistics of the percentage of securities in the total monetary circulation in Albania, by the Central Bank or other financial institutions. The only known forms by the majority are shares and bonds, so other forms mentioned in the law "On Securities" such as derivatives or commercial notes are being forgotten in certain way. This is related to a lack of culture of Albanians regarding capital and different forms of money. In an isolated regime in which these concepts were called "bourgeois", was virtually impossible introduction to these concepts. So the only possibility to face with securities Albanians had after 1990, with the first privatizations. The first plans for privatization began to design since the first years of democracy, but strong deficiencies were observed on this market. Albania also had no opportunity to learn from the region, which was in the same situation with it.

In 1995 came the Presidential Decree No. 1030, which legalized privatization of state assets through the so-called bills being the first forms of securities in Albania. In this way all Albanian citizens became shareholders in state-owned enterprises through privatization through treasury bills. A year later, the Albanian parliament passed the Law no. 8080, date: 01.03.1996, "On Securities", paving the way for the creation of the Securities Commission, as a self-regulatory organization to issue rules and regulations that regulate its internal operations and makes them binding to the ASM itself and the participants in the market too. A soft spot of the privatization process, can be mentioned the fact that the issuance of treasury bills were made through a public offering. Perhaps another form would have been the first inclusion of these state-owned companies on the stock market and then their privatization. This would have been a good opportunity, for the ASM to take a qualitative development. But we are dealing with a newly emerged state from a long dictatorship and the lack of human resources in this area and with monetary insufficiencies to hire foreign experts, in order to grow up this important financial institution.

Experiences such (privatization of state enterprises through public offering) are almost without exception, in all countries of Central and Eastern Europe. A significant proportion of companies that are currently listed on the respective stock markets of these countries, are companies arising from privatization in this form (mention Poland, Hungary, Slovenia, Croatia and Bulgaria). In Albania, public offerings as a method of privatization, did not apply in any of the big privatizations carried out during 2000 as the privatization of the "National Commercial Bank" (Banka Kombëtare Tregtare BKT), diary Factory "Ajka", the cement factories in Fushe-Kruje and Elbasan, beverages Cantina "George Kastrioti Skanderbeg" etc., or subsequent privatizations as the "Savings Bank"(Banka e Kursimeve), "Albtelekom", OSHEE (Operator of the Electricity Distribution), "AMC" (Albanian Mobile Communications", "Tirana Beer" (Birra Tirana) (Merollari, 2012).

ASM finally broke the Bank of Albania on July 1,2002 , to continue with its organization and functioning as a joint stock company with two levels of administration. 
The largest issuer of securities in Albania is the Albanian Government. According to the Law on Entrepreneurs, Companies and Joint Stock Companies with public offering, the three of them have the right to delivery shares in the market, something we have not seen yet. The only body listed on Tirana Stock Market is the Ministry of Finance (as the representative of the Albanian government). The lack of a consolidated capital market makes the cash itself to move slowly. Buyers of securities so far have not purchased on stock market shares of companies in which they are made co. Thus, we still are dealing with an informal and unconsolidated market. (T. Bachner, 2009). But this is to the detriment of the business itself and the one who buys these securities, because if a market of securities would exist, everyone would have the opportunity to compare demands and supplies, determining the real value of the shares purchased.

To date, the institutional framework to some extent is established. We have institutions such as the Ministry of Finance or the Central Bank of the Republic of Albania or the Financial Supervision Authority, which have very small and unconvincing steps and in the establishment and functioning of the Albanian Stock Market. So it seems that the state itself is reluctant, for not having a functioning stock exchange. So far it seems that the Government is satisfied with the traditional forms of financing. It seems that public debt remains the preferred form of our state. On the other hand the private sector would not dare to blow it up first, in the absence of a strong state support. Due to the new fiscal reform, it seems that the number of so-called VIP business will grow. This will also lead to increasing the number of businesses that meet the requirements to be listed on the stock exchange. It seems no business do not see the stock exchange as an opportunity to increase liquidity. Given the informality that exists within the Albanian enterprises, the stock market is something which still seems distant.

One of the other reasons of stock market dysfunctionality is the fact that the reforms undertaken by the Albanian government have not affected this sector. Financial reforms to date were mainly institutional which means that they have affected more commercial banks. This is significantly linked with the financial crisis of 1997, with the so called "pyramid schemes". It was a great shock for the Albanian consumer, who lost faith in the banking sector. It took time for Albanians to hold up their savings in banks. But even today as this mentality has gone up somewhere, capital market is still not where it should. A strong financial system to be completed should have in its composition, diversity of financial institutions, like banks and non-bank. So far business has felt comfortable with this system and it seems that it is not making efforts, itself first, to change this reality. Another aspect worth mentioning is the fact that for the ease of organization, Albanian enterprises have mostly preferred Limited Liability Companies as their organizational forms, staying away of Joint Stock Companies, which are seen as more major forms of organization and far from the Albanian business culture. (Sh. Cani, 2000) It is worth mentioning here also the legal facility that offers creating a LLC compared to a JSC, where the first element is the basic capital. For a LLC this is only $100 \mathrm{ALL}$.

Informality is one of the reasons that do not make functional ASM. All companies, regardless of not meeting the requirements to be listed on the stock exchange also have informality inside. This phenomenon occurs in several forms such as: employees are provided with the minimum wage, regardless of their real wage, some have no insurance at all, so working on "black". Or the company's revenues are not declared in accordance with the real revenues. Such phenomena cannot take place in a company listed on the stock exchange. According to the Bank of Albania, the quantitative criteria to be met by a company to be listed on the stock exchange are fulfilled by Albanian businesses, met in large measure, referred to here and the statute of ASM. (Sh. Cani, 2000)Seems that the statute of ASM, has offered these facilities, then the cause remains business itself has not agreed to see the stock market as a means of financing.

\section{Conclusions}

ASM is set in a good legal framework and institutional. Factors of its malfunctioning really should be found elsewhere. As a young capitalist state still, "the hand" of the state is seen as necessary to make the non-banking financial institution to function. So we first need the government's willingness to implement the Stock Exchange. What would be some of the ways? Firstly, listing in the stock market all those companies in which the state still has shares. This would be a good pulse in order to encourage other companies, which until now have seen this as an obstacle to be listed them first. Through participation initially and then starting the first issue of shares, the companies that meet the requirements will begin to participate in the market to buy shares and then begin to trade stocks themselves. There is a positive trend for businesses to participate in societies in which the state is part of capital. This relates to the question referred, the fact that the state still maintains high influence on the market.

The securities market still remains poor. Everyone thinks that only securities are shares traded on the stock exchange but in fact this is not true. We should have a diversification of marketable securities. On the securities law we can find a variation of them, it seems that the law "has learned" from the experience of European countries. It is not 
known from corporate managers and turns us to the human resources problem mentioned above, which appears that after so many years the peaks on management system are not yet met, to think of new forms of investment, but remained satisfied with traditional forms of financing their business. All business managers, who meet the requirements for listing on the stock exchange, would prefer getting credit as ways of financing their business. Given the experiences and regional and global trends, lending by banks, more and more is becoming a form of old and probably difficult financing. If the number of businesses will increase their demand for financing, the commercial banks also will not be able to meet these needs. So there still isn't a culture which can understand that listing on the stock exchange is a good form to increase liquidity. Thereby, business has not made any pressure on the government for the necessity of starting the operation of the ASM. So far neither the private party as well as state authority has not encouraged each other to take this step.

In 2010 it was rumored to activate the ASM where from the Minister of that time there was a talk of strategic investors who were willing to help in its activation. The government, in its plan, predicts to make part of this stock market the banking system, including all commercial banks, whose situation has been very good in recent years, giving it a control package and the possibility of developing some of the policies of the stock market management. This will certainly have a positive impact on the Albanian market that increasingly wants to feel as a part of the major European market and global one. First Impacts to be felt would be that of: reducing informality, the promotion of competition between companies or attracting foreign investments directly or indirectly. Stock Market is an unavoidable reality, which sooner or later will have to undergo public and private actors in Albania. Lawmakers of the Securities Law seem to have been more visionary yet, when they envisaged the possibility of opening other stock markets, except Tirana. As a relatively new law drafted under the consultancy of European countries, this looks good supporter of the activity of ASM in the future.

The situation is quite positive and Albanian economic and financial environment is becoming more suitable for the development of the exchange. Signals are optimistic, as by the development of demand for capital instruments, as well as by the development of the supply of these instruments. Obstacles to be overcome by the will of both parties, both public and private, are surmountable. Growing demand expressed in increased savings and prospects for the development of financial institutions that invest in capital instruments. Likewise, there is growing interest of foreign investors seeking to invest in capital markets in developing countries, where the expected profits are higher. (Merollari, 2012)

\section{References}

Law No. 9901, dated 14.04.2008, "On Enterpreneurs and Trading Companies".

Law No. 9879, dated 21.02.2008 "On Securities".

World History and civilizations,(2002), Volume 2, Tirana, 2002, Toena Publications.

K. Merollari, (2012), "Theory and financing strategies of companies. Their financing problems in Albania", Tirana, 2012.

T.Bachner, EP Sehuster, M. Winner, (2009) "Twinning Project", Tirana 2009.

Sh. Cani, M. Muço, T. Baleta, (2000), "Banking system: Issues of its development", Tirana.

J. Dine, M. Blecher, (2009), Commentary of the law no. 9901 "On Enterpreneurs and Trading Companies", Tirana, 2009, GTZ.

Bank of Albania, (2012), "Monetary Policy in Albania: From the Past to the Present", 10th International Conference of Albanian Bank, Tirana, 26 Oct. 2012.

Bank of Albania, (2011), "Building the Future through Financial Culture", Sessions of the $9^{\text {th }}$ International Conference of the Albanian Bank, 15 Sept. 2011.

Gilson, Ronald J., (May 2000), "Globalizing Corporate Governance: Convergence of Form or Function". Stanford Law and Economics Olin Working Paper No. 192; and Columbia Law and Economics Working Paper No. 174. Available at SSRN: http://ssrn.com/abstract=229517 or http://dx.doi.org/10.2139/ssrn.229517.

Comerton-Forde, Carole and Rydge, James, (April 2004), "A Review of Stock Market Microstructure". Available at <SSRN: http://ssrn.com/abstract=710801> or http://dx.doi.org/10.2139/ssrn.710801.

Siems, Mathias M., (September 10, 2008), "The Foundations of Securities Law". Available at SSRN: http://ssrn.com/abstract=1089747 or http://dx.doi.org/10.2139/ssrn.1089747.

Claessens, Stijn and Dasgupta, Susmita and Glen, Jack D., (September 1995), "The Cross-Section of Stock Returns: Evidence from Emerging Markets". World Bank Policy Research Working Paper No. 1505. Available at SSRN: http://ssrn.com/abstract=604986.

Websites

www.qpz.gov.al

www.tse.com.al

www.londonstockexchange.com

www.amf.gov.al

www.bankofalbania.org

www.minfin.gov.al 